\title{
Development of Character Education Model for Gender Perspective Jathil Obyog Reog Ponorogo Dancers
}

\author{
Rido Kurnianto ${ }^{1}$, Nurul Iman ${ }^{2}$, Sigit Dwi Laksana ${ }^{3}$ \\ \{kurnianto.mama@gmail.com $\left.{ }^{1}\right\}$ \\ Study program of Islamic banking, Faculty of Islamic Religion, University of Muhammadiyah \\ Lampung, Lampung, Indonesia ${ }^{1,2,3}$
}

\begin{abstract}
One of the art variants of Reyog Ponorogo is Reyog Obyog. One of the dance components is the jatil dance (horse braid) which is performed by women. In this dance, what was originally a satirical visualization transformed into an "erotic" dance and subsequently gave birth to a "negative" image of the Jatil Obyog dancer as a cheap woman which then gave birth to exploitative and subordinative treatment. Meanwhile, on the other hand, jatil obyog dance contains very strategic character values to be used as a model for character education based on the local wisdom of Reyog Ponorogo. This study used a qualitative method with a feminist approach to finding a character education model for the Jatil Obyog dancers. This research found the following findings: (1) patriarchal culture has created a negative image of the Jatil Obyog dancers; (2) the character values of the Jatil Obyog dance, which is self-confidence, optimistic, never giving up, creative, and orderly, are very strategic as pillars of the gender perspective character education model; (3) A gender perspective character education model based on local wisdom of the Reyog Obyog Jatil dance is an alternative character education development for prevention and overcoming violence against female jatil dancers in Reyog Ponorogo art.
\end{abstract}

Keywords: Model, Character Education, Gender, Women, Jatil Obyog

\section{Introduction}

Jatil Obyog is a type of jatil dance in the art performance of Reyog Obyog. Reyog Obyog is Reyog Ponorogo art which is alleged to be the origin (origin) of Reyog Ponorogo. Obyog means together or cooperation. Kumorohadi interpreted it in Javanese to greet gawe [1], pp. 2324] (working together). It is called obyog because this reyog was performed from, by, and for the people. This means that the obyog stage is a stage that comes from the people, is initiated by the people, and is performed for the people. In the basic manual, obyog is interpreted somewhat differently, which is related to the type of accompaniment or wasp before the stage [2, p. 19]. In the context of Reyog Obyog, the difference in meaning is not contradictory, as written by Kurnianto, that Reyog Obyog is not bound by strict performance rules (pakem), prioritizing the values of togetherness and fun (entertainment) for the players and the people involved in the show, including the audience and the audience, and therefore often referred to as folk art [3, p. 79]. The obyog's performance was marked by the echoing of obyog accompaniment or beats as a signal for the players to gather immediately and simultaneously informing the audience that the stage would begin soon [4]. 
Reyog Obyog are usually performed in open areas, such as village fields, large house yards, fork or crossroads, the yard of the village hall, and others where it is possible to perform performances freely. Soemarto wrote down the characteristics of Reyog Obyog's performance, as follows: (1) jatil dancers were played by girls and often did not use eblek (braided horse); (2) the audience can mingle in it; (3) not using a storyline or no scenario; (4) the number of players is not stipulated; (5) performances are often extreme, such as the attraction of pemarong shouldering jatil dancers or carrying pembarong, and even often improvising dance by making modifications from various other music genres, such as dangdut music, gambyong, campursari, koplo, and so on [5, p. 22].

Concerning the Jatil dancers on the Reyog Obyog, Kurnianto wrote the following: (1) Jatil dancers tend to bring individual dance characteristics, each jatil dancer can perform different dances even on the same stage because there is no obligation to dance. do exercises before the stage; (2) there is no obligation to wear uniforms, depending on the tastes of each panari, so that it looks colorful; (3) the make-up also depends on the request of each dancer, usually, the makeup is pretty to the point of "menor". A jatil obyog dancer show in Figure 1.

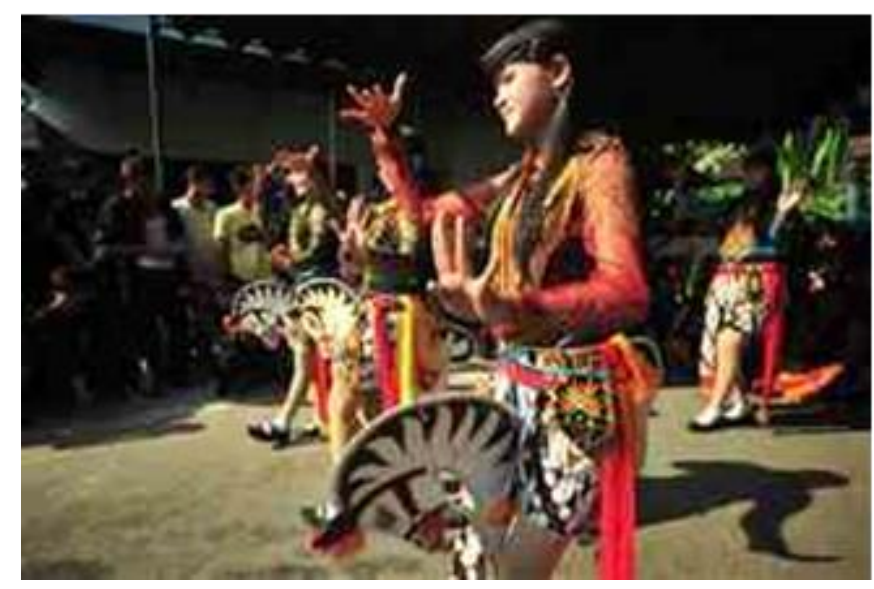

Fig.1. A Jatil Obyog dancer

Furthermore, some of the characteristics of the Jathil Obyog movement were as follows: (1) The movements that were carried out were exploratory in music and solah movements as if at random; (2) The movements are more dominated by hip movements, such as egolan movements (lenggak-lenggok), breaking, pushing the buttocks to the right and left, the dance model tends to mimic the movements of the dangdut dance in general; (3) The application of techniques tends to be arbitrary; (4) Many movements are performed jokingly, looking at other dancers and occasionally stopping according to the dancer's will; (5) Dance movements are also dominated by movements of jaipong, dangdut, and improvisation at the initiative of each dancer; and (6) often do not use eblek as permanent property.

On one hand, the Reyog Obyog's performance model is a very good model for conservation, because it is fully supported by, from, and for the people of Ponorogo. But on the other hand, the context of this entertainment-based populist stage has unwittingly created a gender bias in jatil dancers. The fact about this manifests in the following points; (1) the edrek dance (edotan: Javanese), which was originally a form of satirical visualization, ridiculed Brawijaya $\mathrm{V}$ because of its leadership policies which tended not to side with the people, turned into hip dance as a 
gift aimed at the pemarong, ganongan and the audience which led erotic dance; (2) improvisation that tends to follow the development of music from other genres outside Reyog, including dangdut, campursari, koplo, gambyong, provides a greater opportunity for the development of the erotic side of edrek dance; (3) edrek as a gift to the audience becomes an opportunity for "violence" or "harassment" in the form of a pinch or physical touch by the audience to the jatil dancer; (4) the effect of point 3 further allows the audience to perform the "sawer" action so freely that it often touches the body of the Jatil dancer. The facts above have further resulted in the emergence of a negative stigma attached to the Jatil Obyog dancers, such as; "cheap" women, bad women, and so on.

Meanwhile, on the other hand, Reyog Obyog's stage was also full of character values or local wisdom which had great values, among others; self-confident, unyielding, creative, disciplined. Local wisdom contained in the Jatil Obyog dance is very strategic to minimize and even eliminate the gender bias that has been happening and experienced by Jatil Obyog dancers.

Based on the facts about gender bias above, this article will analyze more deeply the character values contained in the Jatil Obyog dance to minimize or even eliminate gender bias as well as the negative stigma that occurs in the Jatil Obyog dancer dance through the development of the Reyog Ponorogo character education model.

\section{Method}

This study chooses a qualitative approach using a participatory paradigm, to study the development of a character education model for the Jatil dancer's gander perspective on Obyog Reyog Art. Based on the research problem, the data to be collected is a variety of information from informants (Konco Reyog) in several places/locations where the Reyog Art Association contains their understanding of the cultural formulations depicted in the art of Reyog Ponorogo and the basic framework of educational values. a character that can be broken down from the value/meaning that is displayed in the symbol of the instrument and the variety of the Reyog Obyog dance. The data needed in this study have a more emic perspective, namely data collected based on expressions, language, ways of thinking, and views of research subjects. Evaluation and interpretation of information descriptions or data presentations are derived from research subjects.

\section{Results and Discussion}

\subsection{The Role of Women in the Art of Reyog Ponorogo}

Jatil obyog with female dancers has no historical roots. The history of the jatil dancer Reyog Obyog was a man who was dressed in women's clothes and make-up. This is because the substance of Jatil Obyog is to carry the message of "satire" aimed at Brawijaya V, who because of his empress's domination, he behaves like a "sissy". However, the presence of female jatil dancers has contributed greatly to the dynamics of Reyog Ponorogo art. The change of Jatil Obyog dancers to women occurred at the request of a stage during the reign of President Soeharto at the Jakarta Fair in 1988 [3, p. 110] who asked for the Jatil dance to be performed by women. Although at first there was controversy over the change of jatil dancers to women, after 
seeing the results of performances in Jakarta were very beautiful, it had an impact on changes in the jatil dancers, Reyog Ponorogo, which occurred in almost all Reyog Groups [6].

The inclusion of women in the Reyog Ponorogo dance component becomes a new chapter for women's roles in Reyog Ponorogo [5]. Opportunities for women to reinforce their roles and participation are getting stronger along with the strengthening of appreciation of Reyog Ponorogo art from all components of Ponorogo society, including from Islamic education circles and Islamic boarding schools. At the same time, the satire content in jatil dance began to fade along with the tendency of creation and improvisation in the name of "the demands of the times". Dangdut, koplo, campursari, gambyong, and other music began to color the Reyog Ponorogo stage, especially the Jatil Obyog dance. The role of women in the Jatil Obyog dance is getting stronger because it is considered more by the demands of this development.

In certain contexts, the respect for women in the case of the jatil dancer Reyog Obyog is a sign of affirmation towards gender equality. It is this opportunity that deserves to be fought for so that their participation and role can become a qualitative action in the framework of the preservation and development of Reyog Ponorogo art, and not vice versa, become a "boomerang" for Jatil dancers.

\subsection{The Gender Bias in Jatil Obyog Dance}

As explained above, that the occurrence of gender bias stems from the dynamics that occur in Reyog Obyog. The development of dance creations, including the jatil dance, is so dynamic that it unconsciously "removes" the symbolic pillars of the obyog standard developed from the legend of Suryongalam (Surukubeng), which is derived from satire (satire). The demands of the stage and the context of the times were important factors in the birth of improvisation in the Jatil Obyog show. The demand for the stage gave birth to the attitude of the Jatil Obyog dancers to make adjustments, such as making up pretty or "menor", which tends to create stereotypes. Dance improvisation requires Jatil Obyog dancers to make adjustments to the trends in music trends that are developing and liked by the community, such as dangdut, campursari, gambyong, and others. In Kurnianto's writing, the occurrence of gender bias in the Jatil Obyog dance is as follows:

a. Edrek Dance for Ganongan Dancers.

The substance of this dance is a gift for the Ganongan dancer who has finished performing the dance action, which is to display his skill in dancing the Ganongan dance through a charming dance action. One by one the Jatil Obyog dancers gave an edrek dance in the form of a hip lenggak lenggok dance and even seemed "seductive" to where the ganongan dancers were so close and often in contact with the ganongan's limbs. Edrek dance for ganongan show in Figure 2.

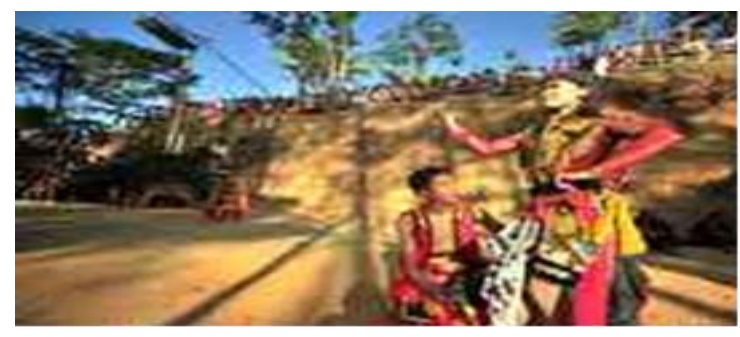

Fig.2. Edrek Dance for Ganongan 
b. Edrek Dance for Pembarong

As in the edrek prize for Ganongan dancers, this edrek dance is also the same pattern, namely the Jatil Obyog dancer advancing towards the pemarong who has completed the action by swinging his hips and smiling impressively "teasing" up to a very close distance like what happened to the Ganongan dancer. Edrek dance for pembarong show in Figure 3.

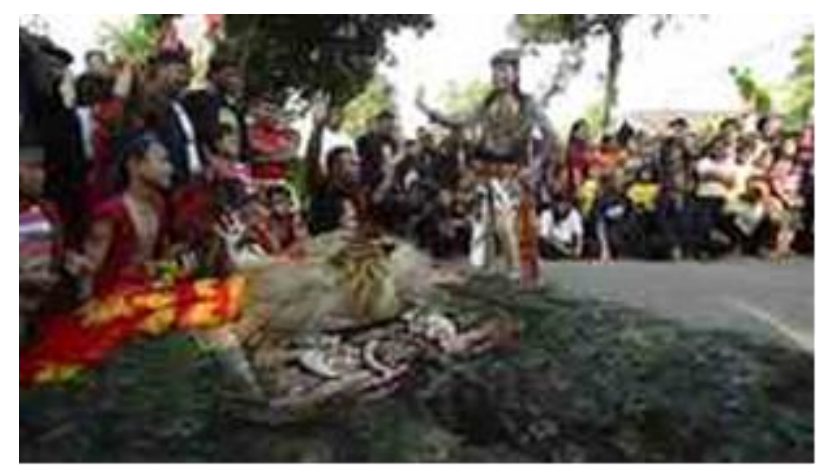

Fig.3. Edrek Dance for Pembarong

c. Gambyong Dance

The Jatil Obyog dance which is improvised from the Ganongan dance is usually performed in freelance music performed by Reyog Ponorogo music. Jatil Obyog dancers are very free to dance according to the music that is being sung. The part of the Jatil Obyog dance performance that was most excited was the dance session, which triggered all the audience to sing and dance together [7]. At this dance session, the audience can freely approach the Jatil dancers to just dance or to be able to touch the Jatil dancers' bodies. During this session, saweran was also given and sometimes the performer was used to touch the Jatil dancer's body. Saweran for jatil obyog show in Figure 4.

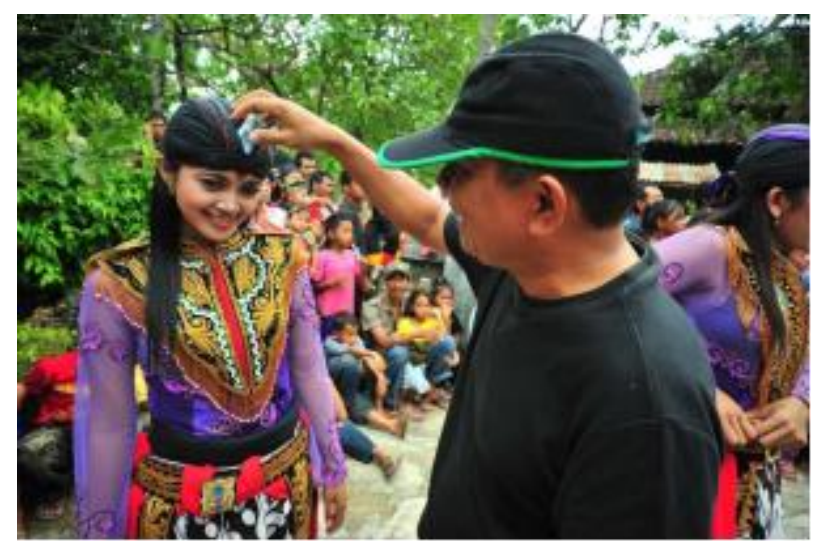

Fig.4. Saweran for Jatil Obyog 
In the three edrek aimed at ganongan dancers, pembarong, and the audience, if you pay close attention to the movements of the jatil dancers, it will consistently start from the right side. There is no explanation for this fact because there is no research that explains this. There are several possibilities, as written by Kurnianto, that the movement from the right is due to the following factors: (1) the demands of the standard or standard guidelines for the jatil dance; (2) moral demands as a tradition of Javanese people that have taken root, namely the culture of unggah-unnguh (manners) which in Javanese culture or tradition, for example, is shown to the right [3, p. 111]. If this is true, it means that the edrek dance also stores local wisdom that can be included in the character or value of the Jatil Obyog dance.

\subsection{The Character Education Model of the Jatil Obyog Dance}

The characters contained in the Jatil Obyog dance are creative, confident, disciplined, and never give up. The creative character [8] is visualized by dynamic dance movements and is very flexible to accept other dance aspects, such as dangdut, campursari, gambyong, and so on. A confident character is visualized in the movements of a horseman who is agile, skilled, and always on standby. Discipline character appears in the compactness of the dance accompanied by obyog music, even though each jatil dancer often performs different dances. Meanwhile, the unyielding character is seen when advancing to battle with Singo Barong (Barongan) [9].

The local wisdom contained in the Jatil Obyog dance, as described above, is strategic enough for the preservation and development of Reyog Ponorogo art, as well as an effort to raise new awareness about the importance of a role for women in the public sector to increase the balanced competitiveness of women and men regardless of gender, as well as a motivation that produces a high work ethic, related to the role and participation of women in the Ponorogo jatil dance. To realize the big ideas above, education is the main consideration in realizing it. As Riningsih wrote, the theme of gender should not only be studied in a theoretical manner but also be required to be applied in a concrete manner [10, p. 25].

The gender perspective character education model in Jatil Obyog dance, on the one hand, will be a major activity related to gender education. Meanwhile, on the other hand, as written by Iman, et al., Character education in Reyog Ponorogo art will be a very strong basis for preservation because it is fought for by the supporting community in various forms [11, p. 32]. This was confirmed by Hadiwinoto, that conservation must live and develop in the community. Conservation must be fought for by the wider community [12, p. 30].

Referring to the Reyog Ponorogo art character learning model, which has been written by Kurnianto, et al., Package 4 about the values of Islamic education in the art of Reyog Ponorogo, the sub-chapter of the Reyog dance variety, includes the dhadhak peacock dance, warok dance, jatil dance, pujangganong dance, and dance kelanasewandana [9, pp. 77-104] can be used as a basis for developing a character education model for the Jatil Obyog Reyog Ponorogo dance.

The components of the development of the Jatil Obyog dance character education model with a gender perspective are as follows:

- The object of implementation is the Mini Reyog Group, with the consideration of facilitating the cultivation of character as well as strengthening the continuing heritage of Reyog's art.

- The learning design follows the inquiry model which provides full opportunities for students to discover for themselves the Jatil Obyog dance character.

- The learning method is discussed through observing the Jatil Obyog dance video based on the legend of Suryongalam (Surukubeng). 
- The gender perspective is directed at the findings of the character based on the legend of Suryongalam (Surukubeng) to restore the basis of Jatil object dance creations as satire. Gender perspective is also directed to the role and function of women in the Jatil Obyog dance.

- The learning evaluation is directed at the practice and dance creations developed by the student according to the characters found in the Jatil Obyog dance.

\section{Conclusion}

The gender bias that occurs in the Jatil Obyog Reyog Ponorogo dance will depend on the attitudes of all parties. All have the right to determine whether the cultural thinking pattern can be changed or that gender bias will continue to be cultured. The role and participation of women who have contributed greatly to the preservation and development of Reyog Ponorogo art through the Jatil Obyog dance should be a strong basis for building mutually beneficial relationships with fellow Konco Reyog according to their respective roles and functions.

There may be many options that can be chosen as an effort to fight for the position of female Jatil Obyog dancers, but the world of education is allegedly the most effective for massive movements towards affirming the noble status of women through learning the character of Jatil Obyog dance with Reyog Mini as the basis for its implementation.

\section{Acknowledgment}

We would like to express our gratitude to the Directorate of Research and Community Service, Deputy of Strengthening Research and Development of the Ministry of Education and Culture for the 2020 Fiscal Year for funding all PTUPT research activities for the 2020 Fiscal Year based on Decree Number: 8 / E1 / KPT / 2020 and Agreement / Contract Number: 187 / SP2H / LT / DRPM / 2020 dated 9 March 2020. Number 024 / SP2H / LT-MULTI / LL7 / 2020 and Number: 108 / VI.4 / PN-MULTI / 2020 dated 23 March 2020.

\section{References}

[1] T. Kumorohadi, Reyog Obyogan; Perubahan dan Keberlanjutan Cara Penyajian dalam Pertunjukan Reyog Ponorogo. Surakarta: PPS STSI, 2004.

[2] Pemerintah Kabupaten Ponorogo, Pedoman Dasar Kesenian Reyog Ponorogo dalam Pentas Budaya Bangsa. Ponorogo: Pemkab Ponorogo, 2013.

[3] R. Kurnianto Nurul Iman, Sigit Dwi Laksan, Seni Reyog Ponorogo; Sejarah, Nilai, dan Dinamika dari Waktu ke Waktu. Yogyakarta: Buku Litera, 2017.

[4] I. Gunawan and R. T. Sulistyoningrum, "Menggali Nilai-Nilai Keunggulan Lokal Kesenian Reog Ponorogo Guna Mengembangkan Materi Keragaman Suku Bangsa Dan Budaya Pada Mata Pelajaran Ips Kelas Iv Sekolah Dasar," Premiere Educ. J. Pendidik. Dasar Dan Pembelajaran, vol. 3, no. 01, pp. 50-87, 2016, doi: 10.25273/pe.v3i01.59.

[5] S. Soemarto, Menelusuri Perjalanan Reyog Ponorogo,. Ponorogo: Kota Reyog Media, 2014.

[6] H. Wijayanto, E. Kurniawan, and B. Harmanto, "Philosophy of the reyog ponorogo equipment," Trames, vol. 22, no. 3, pp. 289-297, 2018, doi: 10.3176/tr.2018.3.05. 
[7] N. Wardani, F. Kurwidaria, K. Wijayanti, D. Said, K. Saddhono, and D. Wulan, "Folklore Reog Ponorogo: Study on Value of Education for the Community," 2019, doi: 10.4108/eai.27-42019.2286891.

[8] R. Listyarti, "Pendidikan Karakter dalam Metode Aktif, Inovatif, \& Kreatif," 2012, Accessed: Nov. 30, 2016. [Online]. Available: http://openlibrary.telkomuniversity.ac.id/pustaka/99033/pendidikankarakter-dalam-metode-aktif-inovatif-kreatif.html.

[9] R. Kurnianto Nurul Iman, Sigit Dwi Laksana, Modul Pembelajaran Karakter Seni Reyog Ponorogo. Ponorogo: Umpo Press, 2019.

[10] S. dkk Riningsih, Praktik Deskriminasi terhadap Pendidikan Anak Perempuan. Laporan Penelitian tidak dipblikasikan, 2000.

[11] N. Iman, Obyog Garapan Pelajar Santri; 4 Varian Pelestari Seni Reyog Ponorogo. Ponorogo: Wade Group, 2018.

[12] H. Hadiwinoto, "Beberapa Aspek Pelestarian Warisan Budaya," Seminar Pelestarian dan Pengembangan Masjid Agung Demak, Demak, Jan. 17, 2002. 